\title{
Virus antibodies in serum and synovial fluid of patients with rheumatoid arthritis and other connective tissue diseases
}

\author{
J. L. KALLIOMÄKI, PEKKA HALONEN, AND AIMO SALMI \\ From the Departments of Medicine and Virology, University of Turku, Finland
}

\begin{abstract}
Kalliomäki, J. L., Halonen, P., and Salmi, A. (1975). Annals of the Rheumatic Diseases, 34, 43. Virus antibodies in serum and synovial fluid of patients with rheumatoid arthritis and other connective tissue diseases. Rubella and influenza $A(\mathrm{H} 3 \mathrm{~N} 2)$ haemagglutination inhibition (HI) antibody titres and measles complement-fixing (CF), haemagglutination inhibition (HI), haemolysis inhibition (HLI), and ribonucleoprotein gel precipitation (RNP-GP) antibody titres were studied in the serum and synovial fluid of twenty patients with rheumatoid arthritis (RA), two patients with ankylosing spondylitis, and two patients with Reiter's syndrome. Antibody titres were also studied in the serum and CSF of four patients with systemic lupus erythematosus (SLE), one patient with dermatomyositis, and in the synovial fluid only of five patients with osteoarthritic knee effusions.

Antibodies were found with each serological technique used in the synovial fluid of RA patients and the antibody titres were usually at about the same level as in the serum.

The mean measles (HI, HLI, and RNP-GP) antibody titres were 4 to 6 times higher in the synovial fluid of RA patients than in synovial fluid of patients with osteoarthritic knee effusions, but a corresponding difference was not found in rubella and influenza $\mathbf{A}$ antibody titres.

The mean measles antibody titres (CF, HI, HKI, and RNP-GP) were consistently higher in the synovial fluid of RA patients without rheumatoid factor than in the synovial fluid of RA patients with rheumatoid factor. In serum this difference was observed only with the measles CF titres. The mean measles antibody titres were consistently lower in the serum and synovial fluid of the RA patients without the synovial fluid haemolytic complement than in the RA patients with this haemolytic complement. No similar differences were found in the rubella and influenza antibody titres.

No significant measles antibody titres were found in the CSF of patients with SLE or dermatomyositis.
\end{abstract}

Increased levels of viral antibodies have been shown in serum specimens of patients with connective tissue diseases, particularly in systemic lupus erythematosis (SLE) and rheumatoid arthritis (RA); in these studies the most constant finding has been an increased antibody level to measles virus (Phillips and Christian, 1969, 1970, 1973; Hurd, Dowdle, Casey, and Ziff, 1970, 1972; Hollinger, Sharp, Lidsky, and Rawls, 1971; Evans, 1971; Kalliomäki and Halonen, 1972; Laitinen, Vesikari, and Vaheri, 1972; Lucas, Brouwer, Feltkamp, Ten Veen, and Van Loghem, 1972; Stanford, 1972; Laitinen and Vaheri, 1974).

In our previous report (Kalliomäki and Halonen, 1972) measles antibodies were assayed with complement fixation (CF), haemagglutination inhibition (HI), and inhibition of salt-dependent haemagglutination from serum specimens of patients with con- nective tissue diseases. In the present study measles, rubella, and influenza A2 antibodies were titrated simultaneously from serum and synovial fluid specimens of patients with connective tissue diseases, mainly RA. Specimens of CSF were also tested together with serum specimens from a few patients with SLE. In addition to CF and $\mathrm{HI}$ techniques, haemolysis inhibition (HLI) and ribonucleoprotein gel precipitation (RNP-GP) were used in the assay of measles antibodies.

\section{Subjects and methods}

The serum specimens and synovial fluid specimens taken from knee effusions were obtained from 20 patients with classical or definite RA, from two patients with ankylosing spondylitis, and two with Reiter's syndrome. Serum and CSF specimens were collected from four patients with 
SLE and from one patient with dermatomyositis. A serum specimen only was available from one patient with SLE. A patient with RA was considered to be rheumatoid factor negative if the Waaler-Rose titre in the serum was $\leqslant 32$ or if the latex fixation test was negative. The total haemolytic complement was determined in the synovial fluid from twelve RA patients. Synovial fluid specimens only were obtained from five patients with typical osteoarthritic knee effusion. All specimens with connective tissue diseases were collected from consecutive patients treated in the latter part of 1972 in the Department of Medicine, University of Turku. The patients were otherwise unselected, except that only RA patients with knee effusions were taken into the study.

Micromethods (Sever, 1962) for measles CF tests and HI tests have been described elsewhere (Panelius, Salmi, Halonen, and Penttinen, 1971). The measles HLI tests were made according to Norrby and Gollmar (1972), and measles virus RNA specific gel precipitation tests according to Link, Panelius, and Salmi (1973). The rubella $\mathrm{HI}$ tests were carried out by the standardized technique. For the influenza A (H3N2) HI test the inhibitors were removed from serum and synovial fluid specimens with a commercial Vibrio cholerae filtrate (Cholera Filtrate Duphar, N.V. Philips-Duphar, Amsterdam). The influenza $A$ strain used in the preparation of haemagglutinin was A/England/334/68 (H3N2).

The total haemolytic activity of serum and synovial fluid specimens was determined with a standard technique described in detail by Jalava, Kalliomäki, and Mustakallio (1974), the Waaler-Rose tests were performed after adsorption with unsensitized sheep red cells to remove the normal antisheep agglutinins (Svartz and Schlossmann, 1949), and the latex tests with a commercial preparation (RA-test, latex-globulin reagent, Hyland Division, Travenol Laboratories, S.A., Brussels).

\section{Result}

The rubella and influenza A (H3N2) HI antibody titres and measles CF, HI, HLI, and RNP-GP antibody titres in the synovial fluid and serum of RA patients with or without rheumatoid factor are shown in Table $I$.

With each of the techniques used viral antibodies were found in the synovial fluid specimens. In individual RA patients without rheumatoid factor the level of antibody titres was usually the same in synovial fluid and serum, as were the mean titres, except the mean measles $\mathrm{HI}$ titres were slightly higher in synovial fluid than in serum. However, in RA patients with rheumatoid factor the individual antibody titres and mean titres were lower in synovial fluid than in serum. In addition, the mean antibody titres in the synovial fluid of patients with rheumatoid factor were consistently lower than the titres in patients without rheumatoid factor.

When the antibody titres of synovial fluid specimens of RA patients are compared with those of a few patients with osteoarthritic knee effusions (Table II), a difference in measles antibody titres is found. While all mean antibody titres are higher in RA patients without rheumatoid factor, in contrast only measles HI, HLI, and RNP-GP titres are 4 to 6 times higher in the synovial fluid of RA patients with rheumatoid factor than in patients with osteoarthritic knee effusions. Mean influenza $\mathrm{A}$, rubella, and measles CF antibody titres are at the same leve in these patients.

The antibody titres of RA patients cannot be compared directly to the antibody levels in the normal? population since such control specimens were not included in this study, which was designed mainly to compare serum and synovial antibody titres and titres between patient groups. However, if the total mean serum titres of RA patients are compared with antibody titres obtained in the laboratory at the same time, but not in the same tests, with a large number of various diagnostic specimens from other patients,

Table I Geometric mean and range of rubella HI, influenza $A$ (H3N2) HI, and measles $C F, H I, H L I$, and $R N P-G P$ antibody titres in serum and synovial fluid of $R A$ patients with or without rheumatoid factor $(R F)$

Serum/synovial fluid

\begin{tabular}{|c|c|c|c|c|c|c|}
\hline \multirow{2}{*}{$\begin{array}{l}\text { Group and } \\
\text { no. of } \\
\text { patients }\end{array}$} & \multirow{2}{*}{$\begin{array}{l}\text { Rubella } \\
H I\end{array}$} & \multirow{2}{*}{$\begin{array}{l}\text { Influenza } \\
H I\end{array}$} & \multicolumn{4}{|l|}{ Measles } \\
\hline & & & $C F$ & $H I$ & $H L I$ & $R N P-G P$ \\
\hline $\begin{array}{c}\text { RF negative } \\
(\text { no. }=8) \\
\text { Mean } \\
\text { Range }\end{array}$ & $\begin{array}{c}57 / 48 \\
(20-320 / 20-160)\end{array}$ & $\begin{array}{c}68 / 57 \\
(6-768 / 12-1536)\end{array}$ & $\begin{array}{c}32 / 27 \\
(4-128 / 4-128)\end{array}$ & $\begin{array}{c}62 / 104 \\
(10-160 / \\
20-640)\end{array}$ & $\begin{array}{c}320 / 349 \\
(80-2560 / \\
40-2560)\end{array}$ & $\begin{array}{c}10 / 11 \\
(2->128 / \\
2-128)\end{array}$ \\
\hline $\begin{array}{c}R F \text { positive } \\
\quad \text { (no. }=12) \\
\text { Mean } \\
\text { Range }\end{array}$ & $\begin{array}{c}38 / 16 \\
(10-160 /<10-40)\end{array}$ & $\begin{array}{c}16 / 16 \\
(<6-192 / \\
<6-192)\end{array}$ & $\begin{array}{r}9 / 6 \\
(<4->256 / \\
<4-128)\end{array}$ & $\begin{array}{c}143 / 71 \\
(40-1280 / \\
<10-1280)\end{array}$ & $\begin{array}{c}412 / 170 \\
(40-1280 / \\
40-1280)\end{array}$ & $\begin{array}{c}9 / 6 \\
(2-64 / 2-32)\end{array}$ \\
\hline Total mean & $44 / 25$ & $29 / 27$ & $15 / 11$ & $102 / 83$ & $370 / 226$ & $9 / 8$ \\
\hline
\end{tabular}


Table II Rubella HI, influenza A (H3N2) HI, and measles CF, HI, HLI, and RNP-GP antibody titres in synovial fluid of patients with osteoarthritic knee effusions

\begin{tabular}{|c|c|c|c|c|c|c|}
\hline \multirow[b]{2}{*}{ Patient no. } & \multirow{2}{*}{$\begin{array}{l}\text { Rubella } \\
\text { HI }\end{array}$} & \multirow{2}{*}{$\begin{array}{l}\text { Influenza } \\
\text { HI }\end{array}$} & \multicolumn{4}{|c|}{ Measles } \\
\hline & & & $C F$ & $H I$ & $H L I$ & $R N P-G P$ \\
\hline $\begin{array}{l}1 \\
2 \\
3 \\
4 \\
5\end{array}$ & $\begin{array}{r}40 \\
40 \\
<10 \\
20 \\
10\end{array}$ & $\begin{array}{l}48 \\
48 \\
<6 \\
48 \\
<6\end{array}$ & $\begin{array}{r}32 \\
32 \\
4 \\
4 \\
4\end{array}$ & $\begin{array}{r}<10 \\
160 \\
<10 \\
20 \\
<10\end{array}$ & $\begin{array}{r}40 \\
160 \\
20 \\
40 \\
20\end{array}$ & $\begin{array}{r}<2 \\
4 \\
<2 \\
<2 \\
<2\end{array}$ \\
\hline Geometric mean & 17 & 16 & 9 & 13 & 40 & $1 \cdot 3$ \\
\hline
\end{tabular}

Table III Rubella HI, influenza A (H3N2) HI, and measles CF, HI, HLI, and RNP-GP antibody titres in serum and synovial fluid of $R A$ patients without any detectable synovial fluid total haemolytic complement and of patients with synovial fluid total haemolytic complement titre $\geqslant 4$

\begin{tabular}{|c|c|c|c|c|c|c|c|}
\hline \multirow{3}{*}{$\begin{array}{l}\text { Complement } \\
\text { titre }\end{array}$} & \multirow{3}{*}{ Patient no. } & \multicolumn{6}{|c|}{ Serum/synovial fluid } \\
\hline & & \multirow{2}{*}{$\begin{array}{l}\text { Rubella } \\
\text { HI }\end{array}$} & \multirow{2}{*}{$\begin{array}{l}\text { Influenza } \\
\text { HI }\end{array}$} & \multicolumn{4}{|l|}{ Measles } \\
\hline & & & & $C F$ & $H I$ & $H L I$ & $R N P-G P$ \\
\hline 0 & $\begin{array}{l}1 \\
2 \\
3 \\
4 \\
5 \\
6\end{array}$ & $\begin{array}{r}160 / 20 \\
160 / 40 \\
20 / 10 \\
20 / 20 \\
40 / 20 \\
160 / 40\end{array}$ & $\begin{array}{c}<6 / 12 \\
6 / 48 \\
6 / 6 \\
6 / 12 \\
192 / 192 \\
48 / 48\end{array}$ & $\begin{array}{c}16 / 8 \\
4 / 4 \\
<4 / 4 \\
64 / 32 \\
4 / 4 \\
<4 /<4\end{array}$ & $\begin{array}{c}320 / 160 \\
80 / 40 \\
20 / 10 \\
10 / 640 \\
80 / 20 \\
160 / 40\end{array}$ & $\begin{array}{c}640 / 80 \\
320 / 160 \\
80 / 80 \\
2560 / 2560 \\
80 / 40 \\
640 / 160\end{array}$ & $\begin{array}{c}16 / 16 \\
16 / 16 \\
16 / 16 \\
32 / 8 \\
2 /<2 \\
16 / 8\end{array}$ \\
\hline Geometric & mean & $64 / 22$ & $13 / 27$ & $6 / 6$ & $64 / 57$ & $359 / 160$ & $13 / 8$ \\
\hline$>4$ & $\begin{array}{l}1 \\
2 \\
3 \\
4 \\
5 \\
6\end{array}$ & $\begin{array}{c}20 / 20 \\
40 /<10 \\
320 / 80 \\
20 / 10 \\
40 / 40 \\
320 / 160\end{array}$ & $\begin{array}{c}196 / 48 \\
<6 /<6 \\
12 / 6 \\
24 / 24 \\
6 / 6 \\
12 / 12\end{array}$ & $\begin{array}{c}128 / 128 \\
256 / 16 \\
4 /<4 \\
8 / 4 \\
8 / 4 \\
32 / 32\end{array}$ & $\begin{array}{c}160 / 640 \\
1280 / 320 \\
640 / 320 \\
320 / 160 \\
320 / 320 \\
160 / 80\end{array}$ & $\begin{array}{c}2560 / 1280 \\
1280 / 640 \\
640 / 640 \\
320 / 320 \\
640 / 320 \\
320 / 320\end{array}$ & $\begin{array}{c}>128 / 128 \\
64 / 4 \\
64 / 64 \\
2 /<2 \\
8 / 8 \\
4 / 16\end{array}$ \\
\hline Geometric & mean & $64 / 28$ & $14 / 10$ & $23 / 11$ & $359 / 254$ & $718 / 508$ & $18 / 17$ \\
\hline
\end{tabular}

Table IV Rubella HI, influenza A (H3N2) HI, and measles CF, HI, HLI, and RNP-GP antibody titres in serum and synovial fluid of 2 patients with ankylosing spondylitis and 2 with Reiter's syndrome

Serum/synovial fluid

\begin{tabular}{|c|c|c|c|c|c|c|c|}
\hline & & & & & & & \\
\hline \multirow[b]{2}{*}{ Diagnosis } & \multirow{2}{*}{$\begin{array}{l}\text { Patient } \\
\text { no. }\end{array}$} & \multirow{2}{*}{$\begin{array}{l}\text { Rubella } \\
\text { HI }\end{array}$} & \multirow{2}{*}{$\begin{array}{l}\text { Influenza } \\
\text { HI }\end{array}$} & \multicolumn{4}{|l|}{ Measles } \\
\hline & & & & $C F$ & $H I$ & $H L I$ & $R N P-G P$ \\
\hline \multirow{2}{*}{$\begin{array}{l}\text { Ankylosing } \\
\text { spondylitis } \\
\text { Ankylosing } \\
\text { spondylitis } \\
\text { Reiter's syndrome } \\
\text { Reiter's syndrome }\end{array}$} & 1 & $320 / 320$ & $48 / 24$ & $64 / 128$ & $5120 / 5120$ & $1280 / 5120$ & $64 / 64$ \\
\hline & $\begin{array}{l}2 \\
1 \\
2\end{array}$ & $\begin{array}{l}40 / 80 \\
80 / 160 \\
10 / 20\end{array}$ & $\begin{array}{l}96 / 96 \\
96 / 24 \\
48 / 48\end{array}$ & $\begin{array}{c}256 / 2048 \\
32 / 16 \\
<32 /<32\end{array}$ & $\begin{array}{c}5120 / 5120 \\
160 / 80 \\
160 / 80\end{array}$ & $\begin{array}{c}2560 / 1280 \\
160 / 80 \\
160 / 160\end{array}$ & $\begin{array}{c}128 / 128 \\
4 / 4 \\
2 / 2\end{array}$ \\
\hline
\end{tabular}


Table V Rubella HI, influenza A (H3N2) HI, and measles CF, HI, HLI, and RNP-GP antibody titres in serum and CSF of 5 patients with SLE and one patient with dermatomyositis

\begin{tabular}{|c|c|c|c|c|c|c|c|}
\hline \multirow[b]{3}{*}{ Diagnosis } & \multirow[b]{3}{*}{ Patient no. } & \multicolumn{6}{|c|}{ Serum/CSF } \\
\hline & & \multirow{2}{*}{$\begin{array}{l}\text { Rubella } \\
\text { HI }\end{array}$} & \multirow{2}{*}{$\begin{array}{l}\text { Influenza } \\
\text { HI }\end{array}$} & \multicolumn{4}{|l|}{ Measles } \\
\hline & & & & $C F$ & $H I$ & $H L I$ & $R N P-G P$ \\
\hline $\begin{array}{l}\text { SLE } \\
\text { SLE } \\
\text { SLE } \\
\text { SLE } \\
\text { SLE } \\
\text { Dermatomyositis }\end{array}$ & $\begin{array}{l}1 \\
2 \\
3 \\
4 \\
5 \\
1\end{array}$ & $\begin{array}{c}160 /<1 \\
10 / \mathrm{nt} \\
160 /<1 \\
160 /<1 \\
20 /<1 \\
80 /<1\end{array}$ & $\begin{array}{c}48 /<6 \\
384 / \mathrm{nt} \\
768 /<6 \\
48 /<6 \\
<6 /<6 \\
24 / \mathrm{nt}\end{array}$ & $\begin{array}{c}16 /<1 \\
<4 / \mathrm{nt} \\
4 / 1 \\
4 /<1 \\
4 /<1 \\
256 /<1\end{array}$ & $\begin{array}{c}640 / 1 \\
80 / \mathrm{nt} \\
20 /<1 \\
1280 / 1 \\
20 /<1 \\
160 /<1\end{array}$ & $\begin{array}{c}160 /<4 \\
160 / \text { nt } \\
80 /<2 \\
640 /<2 \\
40 /<4 \\
320 / \text { nt }\end{array}$ & $\begin{array}{l}16 /<1 \\
16 / \mathrm{nt} \\
4 /<1 \\
16 /<1 \\
<2 /<1 \\
16 / \mathrm{nt}\end{array}$ \\
\hline Geometric mean & & 64 & 61 & 9 & 127 & 160 & 8 \\
\hline
\end{tabular}

rubella and influenza $\mathrm{HI}$ titres and measles $\mathrm{CF}$ and RNP-GP titres fall within the same range but the measles HI titres are 2 to 3 times and HLI titres 3 to 4 times higher in the RA patients.

When the RA patients were grouped according to the presence of haemolytic complement in the synovial fluid it was found that mean titres of each measles antibody tested were higher in patients with haemolytic complement than without (Table III). This difference was not noted in the influenza and rubella antibody titres.

In each of the two patients with ankylosing spondylitis the measles antibody titres were exceptionally high (Table IV), while the influenza and rubella titres were within the usual range as were all antibody titres of the two patients with Reiter's syndrome.

Cerebrospinal and/or serum specimens were tested from five patients with SLE and one patient with dermatomyositis (Table V). Except for 1/1 measles HI titre in two SLE patients and 1/1 measles CF titre in one SLE patient, no antibodies were found in the CSF specimens.

\section{Discussion}

The results of the present study give further support to the earlier findings that measles antibodies in the serum of patients with connective tissue diseases differ from the other viral antibodies. New, though not unexpected, was the similar findings of raised measles antibodies in the synovial fluid of patients with connective tissue diseases. However, no indication was obtained for local production of measles antibodies in joint tissue since no consistent concentration of measles antibodies was found in synovial fluid.

Technical difficulties in interpreting virus-specific IgM antibodies in the presence of rheumatoid factor have been reported and the removal of rheumatoid factor reveals higher titres of CF antibody (Shirodaria, Fraser, and Stanford, 1972, 1973; Stanford,
1972). Penttinen, Wager, Pyrhönen, Leinikki, and Teppo (1974) have found a high incidence of rheumatoid factor in serum specimens negative in the CF test to large numbers of virus antigens. In our study the mean measles CF titres were 3 to 4 times higher in the RA patients without rheumatoid factor than in RA patients with rheumatoid factor (Table I). The presence of rheumatoid factor apparently did not have any effect on measles HI, HLI, and RNP-GP serum titres. In the two patients with ankylosing spondylitis, typically without rheumatoid factor, the measles $\mathrm{CF}$ antibody titres were also at an exceptionally high level.

It was interesting to note that the antibody levels to measles virus in serum and in synovial fluid were lower in the RA patients without total haemolytic complement in synovial fluid than in the RA patients with haemolytic complement. Complement levels are almost always very low in RA patients with a very active joint process. It is possible that in two large joints with active exacerbation sufficient immunocomplexes develop to bind measles antibodies. This would be reflected by lower antibody levels in synovial fluid and also in serum. Since similar lowered levels were not found in influenza and rubella antibodies it would indicate specificity for measles antibodies. This is an additional fact as discussed above for placing measles antibodies in a unique position in patients with connective tissue diseases.

In the report by Phillips and Christian (1970) measles antibody titres were significantly increased in SLE patients with neurological manifestations than in those without. Since the increased levels of measles antibody titres observed in patients with multiple sclerosis (Panelius and others, 1971) are found more frequently in the CSF than in serum (Salmi, Panelius, Halonen, Rinne, and Penttinen, 1972), we decided to study measles antibody titres in the CSF patients with SLE. No significant antibody titres were found, however. The number of CSF specimens studied was too small for definite conclusions and they were collected from SLE and dermatomyositis patients 
only. The recent report by Thomas, Kendall, and Whitfield (1974) indicates frequent neurological symptoms among patients with ankylosing spondylitis, including a syndrome resembling multiple sclerosis. On the other hand, increased levels of measles virus antibody is the only antibody change found consistently in patients with multiple sclerosis (Brown, Cathala, and Gajdusek, 1973).

Could there be similarities between the aetiopathogenesis in the enlarging group of neurological diseases caused by slow virus infections (Gajdusek, 1973) and in some of the connective tissue diseases? The slow virus infection of which measles virus is one of the aetiological agents, may primarily affect the host's cell-mediated immunoreactivity (Ciongoli, Platz, Dupont, Svejgaard, Fog, and Jersild, 1973; Utermohlen and Zabriskie, 1973a, b). Through altered immunoreaction various clinical symptoms may gradually develop, connective tissue diseases and neurological diseases being two of the possibilities.

This study was supported by grants from the National Research Council for Medical Sciences, Finland. The skilful technical assistance of Mrs. Leena Soini, Mrs. Maija Rautiainen, and Mrs. Tuula Lindholm is gratefully acknowledged.

\section{References}

Brown, P., Cathala, F., and Gajdusex, D. C. (1973) Proc. Soc. exp. Biol. (N.Y.), 143, 828 (Further studies of viral antibodies in the cerebrospinal fluid of patients with multiple sclerosis: vaccinia and para-influenza type 1)

Ciongoli, A. K., Platz, P., Dupont, B., SvejgaArd, A., Fog, T., AND Jersild, C. (1973) Lancet, 2, 1147 (Lack of antigen response to myxoviruses in multiple sclerosis)

Evans, A. S. (1971) Ibid., 1, 1023 (E. B. virus antibody in systemic lupus erythematosus)

GAJDUSEK, D. C. (1973) Ann. Clin. Res., 5, 254 (Kuru and Creutzfeldt-Jakob disease: experimental models of noninflammatory degenerative slow virus disease of the central nervous system)

Holinger, F. B., Sharp, J. T., Lidsky, M. D., AND RAWls, W. E. (1971) Arthr. and Rheum., 14, 1 (Antibodies to viral antigens in systemic lupus erythematosus)

HURD, E. R., DOWDLE, W., CASEY, H., AND ZIFF, M. (1970) Ibid., 13, 324 (Virus antibody levels in systemic lupus erythematosus (SLE))

, _ _ _ _ - (1972) Ibid., 15, 267 (Virus antibody levels in systemic lupus erythematosus)

Jalava, S., KalliomäKı, J. L., AND Mustakallio, E. (1974) Scand. J. Rheum., 3, 39 (Haemolytic and conglutinating complement in rheumatoid synovial fluid and serum. Effect of irradiation synovectomy by intra-articular application of radioactive yttrium)

Kalliomäxi, J. L., and Halonen, P. (1972) Ann. rheum. Dis., 31, 192 (Antibody levels to parainfluenza, herpes simplex, varicella-zoster, cytomegalo virus, and measles virus in patients with connective tissue diseases)

LAITINEN, O., AND VAHERI, A. (1974) Lancet, 1, 194 (Very high measles and rubella virus antibody titres associated with hepatitis, systemic lupus erythematosus, and infectious mononucleosis)

-, VeSIKARI, T., AND VAHERI, A. (1972) Acta med. scand., 192, 37 (Virus antibody levels in rheumatoid arthritis and systemic lupus erythematosus)

Link, H., Panelius, M., AND Salmi, A. A. (1973) Arch. Neurol., 28, 23 (Immunoglobulins and measles antibodies in subacute sclerosing panencephalitis)

Lucas, C. J., Brouwer, R., Feltkamp, T. E. W., Ten Veen, J. H., and Van Loghem, J. J. (1972) Lancet, 1, 115 (Measles antibodies in sera from patients with autoimmune diseases)

NoRrby, E., AND Gollmar, Y. (1972) Infect. Immun., 6, 240 (Appearance and persistence of antibodies against different virus components after regular measles infections)

Panelius, M., Salmi, A. A., Halonen, P., and Penttinen, K. (1971) Acta neurol. scand., 47, 315 (Measles antibodies detected with various techniques in sera of patients with multiple sclerosis)

Penttinen, K., Wager, O., Pyrhönen, S., Leinikki, P., AND TePPo, A.-M. (1974) Lancet, 1, 367 (Negative complement fixation tests as an immunopathological finding)

Phillips, P. E., and Christian, C. L. (1969) Arthr. and Rheum., 12, 688 (Virologic studies in systemic lupus erythematosus)

$-, 1970)$ Science, 168, 982 (Myxovirus antibody increases in human connective tissue diseases)
$-11973)$ Ann. rheum. Dis., 32, 450 (Virus antibodies in systemic lupus erythematosus and other connective tissue diseases)

Salmi, A. A., Panelius, M., Halonen, P., Rinne, U. K., and Penttinen, K. (1972) Brit. med. J., 1, 477 (Measles virus antibody in cerebrospinal fluids from patients with multiple sclerosis)

SEVER, J. L. (1962) J. Immunol., 88, 320 (Application of a microtechnique to viral serological investigations)

Shirodaria, P. V., Fraser, K. B., AND Stanford, C. F. (1972) Ann. rheum. Dis., 31, 221 (Technical difficulties in interpreting virus-specific IgM antibodies in the presence of rheumatoid factor)

$-, \ldots,-1$ (1973) Ibid., 32, 53 (Secondary fluorescent staining of virus antigens by rheumatoid factor and fluorescein-conjugated anti-IgM)

STANFORD, F. (1972) Ibid., 31, 330 (A comparison of complement-fixing antibody titres in patients with rheumatoid arthritis and matched controls) 
Svartz, N., AND Schlossmann, K. (1949) Nord. med., 42, 1390 (En ny serologisk reaktion vid kronisk polyarthrit)

Thomas, D. J., Kendall, M. J., AND Whitfield, A. G. W. (1974) Brit. med. J., 1, 148 (Nervous system involvement in ankylosing spondylitis)

UTERMOHLEN, V., AND ZABRISKIE, J. B. (1973a) Lancet, 2, 1147 (Suppressed cellular immunity to measles antigen in multiple sclerosis patients)

- - (1973b) J. exp. Med., 138, 1591 (A suppression of cellular immunity in patients with multiple sclerosis) 